\title{
Politics of Immigration and Language: The Case of Pakistani Residents in Spain
}

\author{
María Isabel Maldonado García ${ }^{1}$ \\ ${ }^{1}$ Department of English Language and Literature, University of Management and Technology, Lahore, Pakistan \\ Correspondence: María Isabel Maldonado García, Department of English Language and Literature, University of \\ Management and Technology, Lahore, Pakistan. E-mail: Spanishprofessor1@gmail.com
}

\author{
Received: October 31, 2017 Accepted: December 2, 2017 Online Published: February 4, 2018 \\ doi:10.5539/ijel.v8n3p36 URL: http://doi.org/10.5539/ijel.v8n3p36
}

\begin{abstract}
The new Spanish nationality law requires a certain level of Spanish language proficiency for the application of Spanish nationality. The law, which is on the Official State Bulletin (BOE-Boletin Oficial del Estado) N. 167, Section I, Page 58, 149 and which was drafted on the 14th of July, 2015, came in effect on the 15th of October, 2015. The new regulation outlined the new requirements for the immigrants to be able to become Spanish citizens. The law was mainly targeted towards the descendants of those Jewish people who were thrown out of Spain in 1492 in an effort of the Spanish government to normalize relations. Nevertheless, all new applicants are somehow affected by it since a minimum knowledge of Spanish language is required, (level DELE A2 according to the Common European Framework of Reference for languages (CEF; Council of Europe, 2001 \& Little (2005)) and a certain cultural and constitutional knowledge as well, to be measured by additionally passing the CCSE exam. These exams, according to the law, are to be administered by Instituto Cervantes, the official Institute of Spanish language of the Government of Spain. This paper aims to study the repercussions and new effects the law is having on the Pakistan Instituto Cervantes Examination Center in terms of enrollments as well as the effects on a specific group of immigrants themselves; the immigrants from Pakistan.
\end{abstract}

Keywords: language policy, Spanish language, immigration, Instituto Cervantes, new nationality law, Pakistan

\section{Introduction}

A "language tests for citizenship" regime refers to a policy, implemented in a growing number of countries of the world, especially in Europe, requiring immigrants to pass language tests in national and/or official languages of the state as major conditions for obtaining citizenship regardless of length of residence, status, employment, income, education and background (Shohamy, 2009).

It is actually a different migration situation characterized by a stable community of Pakistanis, who in the majority of the cases find themselves in a ghetto in Barcelona where they reside and work in businesses or doing petty jobs. In this situation, they may or not need Spanish language to be able to manage their daily routine within the society they live in. In the majority of the cases they utilize their local languages, mainly Urdu and Punjabi, although there are instances where Gujarati has also been found. The second part of the article investigates their Spanish language proficiency measured by the result obtained in their DELE A2 exam. For this purpose, an analysis of their result cards was conducted to figure out what is their original average linguistic proficiency (independently of whether they received Spanish language classes or not).

In this article, the sociolinguistic repercussions of the new nationality law of 2015 by which foreign nationals are required to acquire an A2 level of Spanish language proficiency will be studied in detail. For this purpose, a set of questions was answered by the applicants who come from Barcelona to Lahore and enroll in the Examination Center of Instituto Cervantes in Pakistan. This survey will be aimed to investigating whether the law has had any socio-linguistic repercussions in the lives of these immigrants. The questions were mainly directed to investigate their social set up and the changes in the language acquisition motivations. In addition, an analysis of their result cards will be performed with the goal of finding out if there are common patterns of proficiency in the candidates in any of the four skills.

This problem is important mainly due to the fact that the new language law has created a new reality. This reality has not been investigated to this date. Its results and conclusions can assist language professionals in Spain as 
well as Pakistan with the teaching of Spanish language to immigrants of Pakistani origin. The idiosincrasies of this group of immigrants has not received too much attention from a research point of view. However, just because of this reason, they are highly misunderstood when it comes to Spanish language learning. This research is an effort to bridge the gap.

\subsection{Background}

Instituto Cervantes is the official Institute of Spanish language. It was created as a non-profit organization on May 21st, 1991 by the Government of Spain, under the leadership of its then president, Felipe Gonzalez, with the purpose of spreading the teaching of Spanish language and culture all over the world. This fact was put into effect by article 3 of the law 7/1991, of 21st, March. Instituto Cervantes takes its name from the famous Spanish writer Miguel de Cervantes Saavedra, author of Don Quijote de la Mancha, book published in 1605 and that has been translated into more than one hundred and forty languages (Instituto Cervantes website (a)).

The headquarters of Instituto Cervantes is located in Madrid and it has various objectives:

1) “Organize general and special courses of Spanish language, and that of Spanish's co-official languages.

2) Issue in the name of the Ministry of Education, Culture and Sports the official diplomas of Spanish DELE and organize the examinations to obtain those.

3) Update teaching methodologies and the education of the teaching staff.

4) Support the work of hispanists.

5) Participate in programs to spread the Spanish language.

6) Carry out cultural dissemination activities in collaboration with other Spanish and Latin American organizations and institutions of the host countries.

7) Make available to the public libraries provided with the most advanced technological means." (Instituto Cervantes website (b))

There are many branches of Instituto Cervantes around the world in four continents and many Associated Centers, as well as Examination Centers of the Institute, which conduct the official examinations of Spanish Language. The following table depicts the countries where the branches of Instituto Cervantes are located.

Table 1. Branches of Instituto Cervantes around the world

\begin{tabular}{|c|c|c|c|c|}
\hline EUROPE & AFRICA & ASIA & AMERICA & AUSTRALIA \\
\hline Austria (Vienna) & Algeria (Algiers, Oran) & $\begin{array}{l}\text { China } \\
\text { (Beijing) }\end{array}$ & $\begin{array}{l}\text { Brazil (Rio de Janeiro, São Paulo, } \\
\text { Brasília, Salvador, Belo Horizonte, } \\
\text { Porto Alegre, Recife, Curitiba) }\end{array}$ & $\begin{array}{l}\text { Australia } \\
\text { (Sydney) }\end{array}$ \\
\hline Belgium (Brussels) & Egypt (Cairo, Alexandria) & $\begin{array}{l}\text { Israel } \quad \text { (Tel } \\
\text { Aviv) }\end{array}$ & $\begin{array}{l}\text { United States (Albuquerque, Boston, } \\
\text { Boston University, Chicago, New York, } \\
\text { Seattle, U. of Washington) }\end{array}$ & \\
\hline Bulgaria (Sofia) & $\begin{array}{l}\text { Morocco (Casablanca, Fes, } \\
\text { Rabat, Tangier, Tétouan, } \\
\text { Marrakesh) }\end{array}$ & $\begin{array}{l}\text { Japan } \\
\text { (Tokyo) }\end{array}$ & & \\
\hline Cyprus (Nicosia) & $\begin{array}{l}\text { Syria (Damascus) } \\
\text { This center does not exist } \\
\text { anymore but is still in the list } \\
\text { of operating centers. }\end{array}$ & $\begin{array}{l}\text { Jordan } \\
\text { (Amman) }\end{array}$ & & \\
\hline Czech Republic (Prague) & Tunisia (Tunis) & $\begin{array}{l}\text { Lebanon } \\
\text { (Beirut) }\end{array}$ & & \\
\hline $\begin{array}{l}\text { France (Bordeaux, Lyon, } \\
\text { Paris, Toulouse) }\end{array}$ & & $\begin{array}{l}\text { Philippines } \\
\text { (Manila) }\end{array}$ & & \\
\hline $\begin{array}{l}\text { Germany (Berlin, Bremen, } \\
\text { Frankfurt am Main, } \\
\text { Hamburg, Munich) }\end{array}$ & & & & \\
\hline $\begin{array}{l}\text { Gibraltar (Gibraltar), (close } \\
\text { this branch due to political } \\
\text { reasons). }\end{array}$ & & & & \\
\hline Greece (Athens) & & & & \\
\hline Hungary (Budapest) & & & & \\
\hline Ireland (Dublin) & & & & \\
\hline
\end{tabular}




\author{
Italy (Milan, Naples, \\ Palermo, Rome) \\ Netherlands (Utrecht) \\ Poland (Warsaw, Kraków) \\ Portugal (Lisbon) \\ Romania (Bucharest) \\ Russia (Moscow) \\ Serbia (Belgrade) \\ Sweden (Stockholm) \\ Turkey (Istanbul) \\ United Kingdom (Leeds, \\ London, Manchester) \\ Source: Instituto Cervantes.
}

The ones mentioned above are the main branches of Instituto Cervantes. The branches depend economically from the government of Spain.

In addition, there are "Centros Acreditados" which are affiliated with the Institute and are located in Spain, also "Centros Asociados" (Associated Centers) which are located in different parts of the world and "Aulas Cervantes" which are classrooms affiliated with the Institute. On the other hand, Centros Examinadores are those centers which are private or public but do not depend from the Institute for affiliation, funds or administrative purposes but conduct are private, raise their own funds and conduct the DELE examinations under the guidelines of Instituto Cervantes.

To be able to conduct these examinations the staff of the Examination Center needs to be trained and certified. The training can be taken from any Instituto Cervantes of the world which offers the particular training needed. The teachers receive a certificate for each training course taken.

In the case of examination centers, once the exams have been administered they are sent either to the branch the Examination Center has been assigned or to Madrid, where the exams are collected and then sent to University of Salamanca, where they are checked and given a grade and the report cards uploaded into the system with a registration number the student is able to access through the Cervantes' website by entering it with their date of birth. A transcript then, downloads showing the results the student obtained in the examination in every part of the exam (written, oral, reading and audio). When a student passes the exam, the certificate is then issued.

The official examinations DELE consist of six levels according to the European Framework for Languages. These are A1, A2, B1, B2, C1, C2. In other words; there are two basic, two intermediate and two advanced levels. There are additional examinations such as "A1 escolar" directed to the school going population and ages, as well as other additional ones such as A2/B1. The examination centers as well as the branches, usually conduct these examinations. Other nations that follow this system are France and Germany. Recently these examinations have started for English language as well, besides the ones previously available such as TOEFL, IELTS and Pearsons. The Netherlands also adopted this policy in 2003 (De Jong et al., 2009).

Students who have passed the exams can utilize these certificates for admissions in Universities of Spain, USA and South America, where Spanish language or an additional language is really important. Admission officers all over the world value a high level of proficiency in a specific language (Lloyd, 2014). In Europe, the language also has a high level of prestige, as it is a language of the European Union and one of the six languages of the United Nations. Universities in Europe value multilingual individuals who are able to communicate in multiple set ups and understand different cultural realities.

As recent as October, 2015 new laws have come into effect. The law of 12/2015, of 24 of June to provide nationality to those Sephardic citizens of Spanish origin who would apply for it and the law of 19/2015, of 13 of July by which in order to obtain the Spanish nationality two examinations need to be passed; the DELE A2 and the CCSE (Constitutional and socio-cultural knowledge of Spain).

The required documentation to apply for nationality for reason of residence (where the DELE exams apply) is the following for adults:

\title{
1) Application
}

2) Identity card of the foreigner, residence card of family member of a citizen of the European Union, or registration certificate of the Union. It can be substituted by the authorization of consultation to the Ministry of Justice mentioned in the application. 
3) Complete valid passport of the country of origin.

4) Birth certificate of the applicant, duly translated and legalized.

5) Criminal record certificate from the country of origin, translated and legalized.

6) Marriage certificate from the place where the marriage took place of the married persons.

7) Receipt of having paid the fee.

8) Criminal record certificate from the Penal Central Registry. It can be substituted for the consultation authorization to the Ministry of Justice mentioned in the application model.

9) Census certificate. It can be substituted for the consultation authorization.

10) Diplomas of Instituto Cervantes of Constitutional and Sociocultural Knowledge (CCSE) and proof of knowledge of Spanish (DELE). It can be replaced with the authorization of consultation of the Ministry of Justice contained in the application form. In the case of nationals of a country where the official language is Castilian, exempt from the examination DELE under nationality through residence Regulation, valid passport or nationality certificate attesting exemption. (Note 1)

\subsection{Spanish Nationality Seekers of Pakistani Origin in Spain}

Immigrants of Pakistani origin are found in Spain in their majority in Barcelona. They started settling there in the 1970s (Moreras Palenzuela, 2005). According to Aubia \& Rodriguez Roca (2005) Pakistan was not traditionally a source of immigration towards Spain. Things have changed considerably in the last thirty years.

The following figure depicts their location comparison from 1993 to 2007.

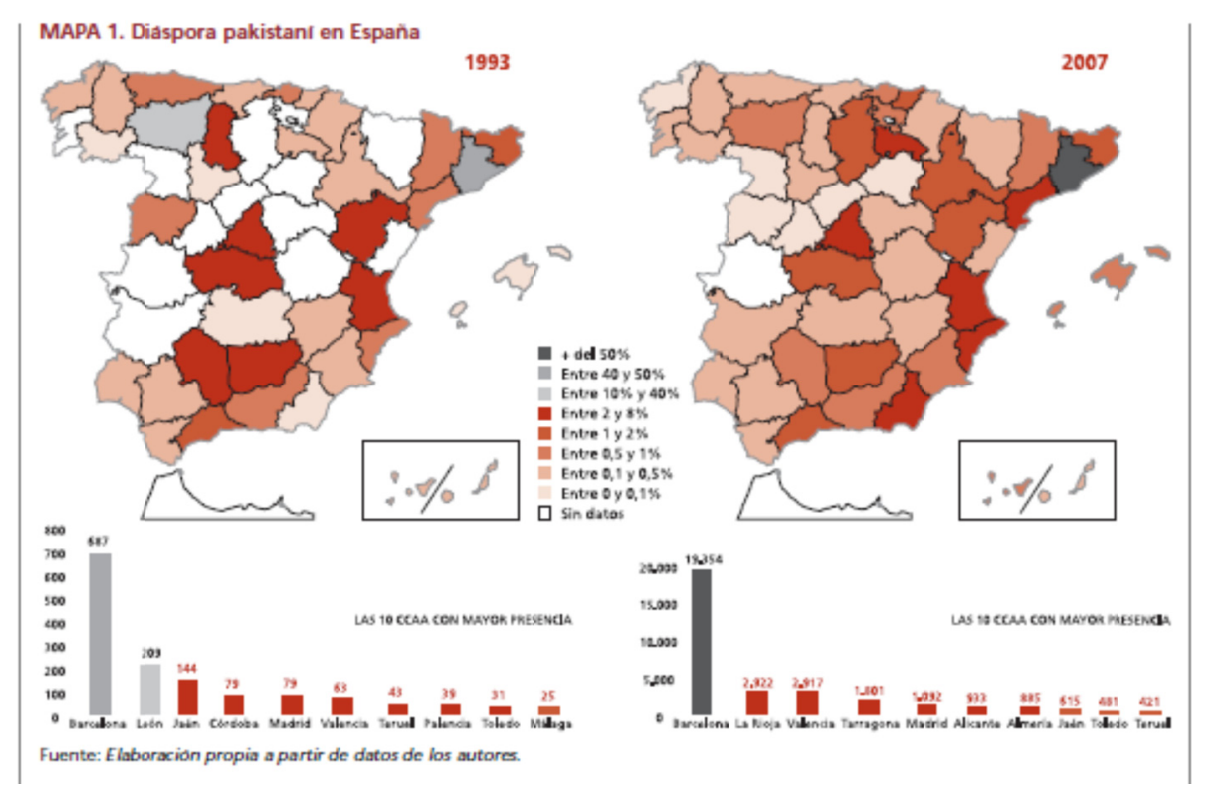

Figure 1. Concentration of the Pakistani population in Spain. Comparison between 1993 and 2007

Source: La Comunidad Pakistaní en España.

The reports and statistics which are available and verify to the size of the community seem to be contradictory. The reason is that, according to a spokesperson of the Spanish Embassy in Islamabad, many of the Pakistanis residing in Barcelona have an illegal status and are not recorded in the census or anywhere else. Certain study states that the size of the male community is of 36,807 while the size of the female population in 2007 was only of 5, 298 members. Hence, the size of the population in 2007 was of 42,105 members. However, in 2015 the size of the population had increased to 77,695, according to the same source (INE, 2016). This is the largest Pakistani population residing in any city of Europe outside of the UK where more than one million people of Pakistani origin reside (The Telegraph, 2008). However the information above, a personal interview with the Ambassador of Spain to Pakistan (Note 2) yielded a different number. According to his Excellency, Mr. Carlos Morales, Ambassador of Spain, Islamabad, the number of immigrants of Pakistani origin living in Spain currently is of 
120,000. However according to Garha, Galeano, \& Valls, (2016) the size of the community in 2014 was of 131,230 .

The reason mentioned by the Ambassador is that when one Pakistani receives nationality, he ensures his family members also receive nationality and join him wherever he lives in the Spanish territory. As it can be seen in this figure, the Pakistani community resident of Spain is concentrated in the area of Barcelona and growing.

The Pakistanis found in Barcelona are mainly males from Punjab although according to INE, only $13 \%$ of Pakistani immigrants are female.
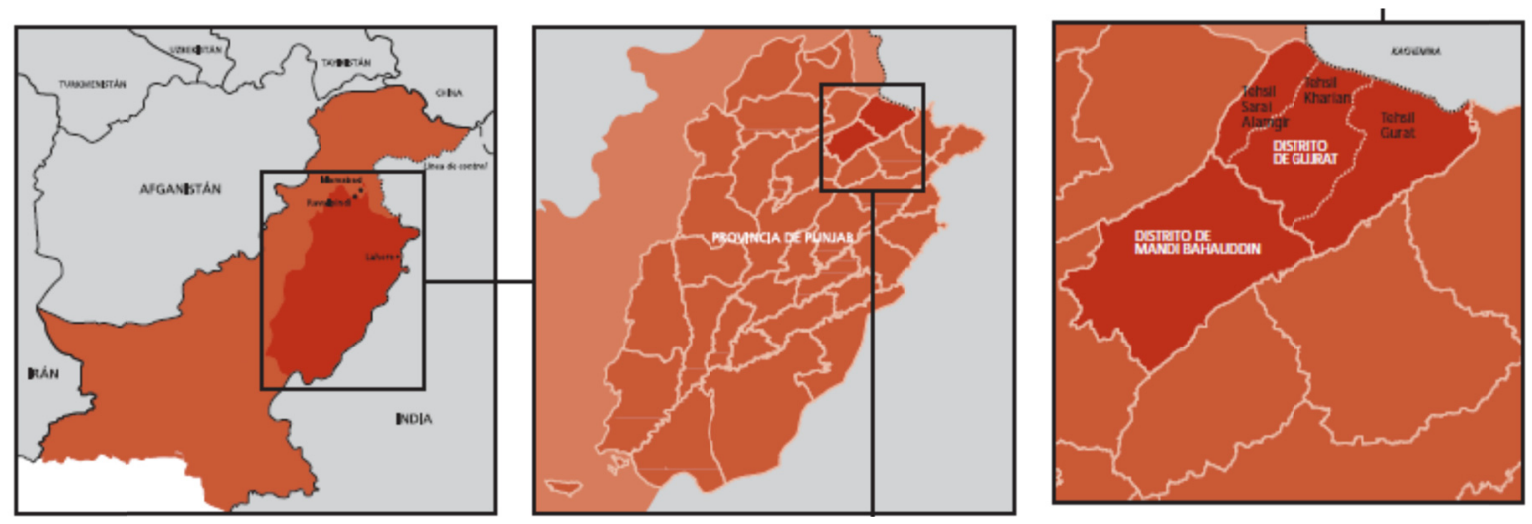

Figure 2. Origins of the Pakistani residing in Spain

Source: La Comunidad Pakistaní en España.

According to Beltran Antolín \& Sais López (2008) “The place of origin of the major part of Pakistanis in Spain is the province of Punjab, specially the districts of Gujrat, with tehsils or areas of Gujrat and Kharian and of Mandi Bahauddin, situated both in the center-north part of the country on the border with Kashmir, from where they have origin some of the first one to establish themselves in Spain.” (2008, p. 409).

From a social point of view, it is of interest to see that the main occupation of Pakistanis residing in Barcelona is commerce. Many of them own restaurants, grocery shops, mobile shops, etc. and the rest perform other type of jobs in the businesses of other Pakistani residents. Many of these jobs do not require qualifications, like restaurant worker, construction and agriculture (La Vanguardia, 2011). In 2001, following a law of regularization of illegal immigrants the number of Pakistani origin immigrants the government was able to record, increased dramatically (Ibid). The reason for this is "the call effect", in other words, when certain immigrants of a specific nationality arrive in a country and realize that there are in fact, employment niches, their immediate reaction is to contact family and friends encouraging them to join them in the country of their residence. Family reunification is another factor for the increase of a specific nationality in a particular place (Riol Carvajal, 2003). Still after so many years the majority of the Pakistani immigration resident of Barcelona is male. In spite of these facilities, a survey concluded that Spain is a weak adopter of multiculturalist policies (Rattansi, 2011). In 2017, not many of these policies have changed. It is quite different in the case of Australia which seems to have a quite effective multiculturalist model (Jupp \& Clyne, 2010). MacIntyre \& Noels (1997A), Ellis \& Barkhuizen (2005) and others worked on the methodologies of analysis of learner language. According to Antolin (2002) the Pakistani community of Spain has the "highest work participation in mining and agriculture." Nevertheless, in 2013 it was reported that in La Rambla of Barcelona the majority of halal butcheries and cellular phone shops are run by Pakistanis while the professional Pakistani chose to migrate to USA, Australia, UK or Canada. (Molina et al., 2013)

Many of the Pakistani origin residents of Spain stay within their community and keep on speaking their mother tongues (Urdu, Punjabi, \& Gujrati, etc.) and never attain a proficient level of Spanish language. Many of them can understand Spanish language but cannot communicate, others can communicate but are unable to write properly and the combinations are multiple. The new law will definitely change that, since the applicants will be forced to pass the DELE A2 exam for which they need to achieve a basic-intermediate level of Spanish language proficiency. 


\subsection{Preparations for the Dele Exams}

Since the new nationality law was approved two years have passed. The Examination Centers of Instituto Cervantes have been flooded with candidates of many nationalities. Since the nationality object of the study of this paper is the Pakistani, information has been extracted which relates to the location where they reside. The majority of the Pakistani immigrant population resides in Barcelona, for this reason information about the centers surrounding this area has been taken. The Barcelona Examination Centers are various (Instituto Cervantes website, 2016):
1) CIEE
2) ELE USAL Barcelona
3) FEDELE Barcelona - BCN LANGUAGES
4) Inlingua Barcelona
5) Universidad de Barcelona
6) Universidad de Vic
7) Universidad Pompéu Fabra
8) ESADE- Universidad Ramón Llull

These centers have limited capabilities to accommodate the flood of candidates. In many cases they run out of space to accept all applicants. The price of the DELE A2 exam in Spain in 2016 is of 124 Euros. (Note 3) To this expense a Pakistani candidate will need to add the price of the preparatory class or classes which will vary from center to center.

Usually, one level of Spanish language takes three months to complete and the courses are geared as well towards this duration. The books usually have twelve lessons or units (Note 4) but they can have a different number of lessons as long as they cover the material required for the exam.

In the majority of the cases the students that cannot find space in the Barcelona Examination Centers register in other surrounding areas centers, such as the ones in Valencia:

1) VALENCIA - Centro de Idiomas Colegio El Prat

2) VALENCI+A - ESIC Business \& Marketing School (Valencia)

3) VALENCIA - FEDELE VALENCIA - Intereuropa

4) VALENCIA - FEDELE VALENCIA - Centro Europeo de Idiomas Ausias March- CEIAM

5) VALENCIA - FEDELE VALENCIA - Costa de Valencia, escuela de español

6) VALENCIA - FEDELE VALENCIA - ENFOREX

7) VALENCIA - FEDELE VALENCIA - Españolé International House

8) VALENCIA - Universidad Católica de Valencia San Vicente Mártir

9) VALENCIA - Universidad CEU Cardenal Herrera (Instituto Cervantes website, 2016)

Nevertheless, candidates have opted for whatever centers are available within the Spanish territory including those in Andalucia, such as Seville, Granada, Malaga, etc. However, a new option is being explored by some Pakistani applicants.

\subsection{Options in Pakistan for Candidates}

Al-Andalus Institute of Languages is an official Examination Center of Instituto Cervantes. It is the only official center in Pakistan accredited by Instituto Cervantes. The institute is located in Lahore and it caters to all applications within the country.

The institute was founded in 2010 by a Spanish instructor, the only native and qualified instructor in the country in the area of Spanish language. (Note 5) The owner of the center had worked since 2004 in Pakistan, teaching Spanish language in various reputed institutions when she finally decided to start a joint business venture with her husband in the form of an institute of languages. Place where students could learn Spanish and other languages and appear in the official exams of Spanish language. In 2012 she sent the application to Instituto Cervantes and it was approved. After training of the teaching staff of Al-Andalus the first examination was held in 2014. Al-Andalus Institute of languages has three instructors of Spanish language. The three of them are native instructors. For the exams these teachers underwent special training as examiners so that the Institute can 
conduct the official exams.

Contrary to their German and French counterparts, (Note 6) Al-Andalus Institute of Languages is not funded by the Government of Spain. The funding comes exclusively from the earnings of the Institute. The beginning times of the Institute were difficult. The owners had taken loans from friends and family to be able to start. Immediately they started promoting Spanish language by way of teaching it in schools such as Aitchison College, Beacon House as a regular subject and other schools such as The New School (TNS) as a summer camp or as an extracurricular activity.

The Institute also provides translations into and from various languages always keeping a focus mainly on Spanish language, while also targeting the local market, for example companies which export, immigration documents as well as educational documents of students who had received admissions and needed a visa, business visa documents, etc.

When the law of October 15th, 2015 was passed, a few students decided to come to Pakistan and spend some time taking classes and preparing themselves for the April examination. The students have found a way to prepare themselves while spending some time with their families in their home country. Other students take online classes and later close to the exam date, travel back to their home country to visit their families and appear for the exam.

When the candidates come to Al-Andalus Institute of Languages for registration of the exams, as per admission policy of the Institute they are requested to take a mock exam. The purpose of the mock exam is to let the candidate and the instructor know in which level the candidate should be placed and whether the candidate is prepared to pass the official exam or, rather, needs further preparation. In the case the candidate passes the mock test he/she is informed that he/she is fully prepared for the exam and has high changes for success. In the case that the candidate fails the mock exam, he or she will be explained his or her errors and recommended to take Spanish language classes in any institute. Many of them refuse to take classes and request to be enrolled for the exam. In that case, the candidate is explained the risks and he or she will be enrolled for the exam. In other cases, the candidate understands that it is necessary for them to improve their proficiency level and either enrolls in some other institute or decides to enroll at Al-Andalus Institute of Languages for classes, as well as for the next DELE official examination. In case they still wish to enroll they can do so if the number of seats is available.

\section{Method}

The present study is aimed at determining what changes have taken place in the lifestyle of the Pakistani community residing in Spain and more specifically in Barcelona, where the majority of Pakistani immigrants are concentrated. In this regard, this study applied a sequential mixed methods approach of research to achieve the objectives; mainly descriptive and analytical methods. For implementing the methodology, an analysis of the language relevant social factors that affect Pakistani immigrants was taken into consideration. These demonstrate the changes that have taken place after the law has been implemented. For this purpose a questionnaire was handed to the candidates and their answers recorded. Furthermore, an analysis will be conducted in regards to the linguistic skills of those candidates who participated in the DELE A2 official exam through their result cards to be able to understand in general whether there are similarities in their educational background as well as their Spanish language proficiency levels.

\subsection{Changes in Approach towards Spanish Language of Pakistani Origin Nationality Seekers}

Spanish language has never been seen as a problem for those residents of Spain of Pakistani origin. Many of them have not felt the need of speaking or learning Spanish language since they were living in an environment which made it easy for them to remain without learning the language. However, the new law has changed all that. Table 2 illustrates the differences in the environment since the law was passed. This data was collected through interviews with the candidates of the DELE A2 exams from Lahore. 
Table 2. Differences the immigration law has made in Spanish language learning in Pakistani origin Spanish nationality seekers

\begin{tabular}{|c|c|c|}
\hline QUESTION & BEFORE THE LAW & AFTER THE LAW \\
\hline $\begin{array}{l}\text { 1. Do you live in a Pakistani } \\
\text { community within Spain or you live in } \\
\text { a mainly Spanish citizen } \\
\text { neighborhood? }\end{array}$ & $\begin{array}{l}\text { The majority of Pakistani nationals live in } \\
\text { Barcelona and stay in close communities where } \\
\text { they do not need to communicate in Spanish } \\
\text { language or keep their Spanish language } \\
\text { interaction to a minimum. }\end{array}$ & $\begin{array}{l}\text { All candidates stated that the majority of } \\
\text { Pakistani nationals live in Barcelona and stay } \\
\text { in close communities where they do not need } \\
\text { to communicate in Spanish language or keep } \\
\text { their Spanish language interaction to a } \\
\text { minimum. }\end{array}$ \\
\hline $\begin{array}{l}\text { 2. Before the law, did you feel any } \\
\text { need to study Spanish language? After } \\
\text { the law? } \\
\text { 3. Do you speak Spanish with your } \\
\text { Pakistani fellows or you speak your } \\
\text { mother tongue? }\end{array}$ & $\begin{array}{l}\text { Residents of Spain of Pakistani origin did not } \\
\text { feel any need to study Spanish language. }\end{array}$ & $\begin{array}{l}\text { All candidates stated that the law has forced all } \\
\text { those immigrants who did not speak Spanish } \\
\text { and want to apply for nationality to study it. } \\
\text { Pakistani residents of Spain continue speaking } \\
\text { their mother tongues with each other. }\end{array}$ \\
\hline $\begin{array}{l}\text { 4. Before the law, were you interested } \\
\text { in learning Spanish language? After the } \\
\text { law? }\end{array}$ & $\begin{array}{l}\text { Pakistani nationals were in general not } \\
\text { interested to learn Spanish. They learned } \\
\text { enough to manage their daily activities and } \\
\text { work. }\end{array}$ & $\begin{array}{l}\text { All candidates stated that to apply for } \\
\text { nationality they have to pass the A2 DELE } \\
\text { exam. This is the only reason they need to } \\
\text { learn the language. }\end{array}$ \\
\hline $\begin{array}{l}\text { 5. Did you enroll in Spanish language } \\
\text { courses before the law? After the law? }\end{array}$ & $\begin{array}{l}\text { Pakistani nationals living in Spain rarely } \\
\text { enrolled for Spanish language classes. }\end{array}$ & $\begin{array}{l}\text { All candidates stated that Pakistani nationals } \\
\text { living in Spain are now enrolling for Spanish } \\
\text { language classes in large numbers. }\end{array}$ \\
\hline $\begin{array}{l}\text { 6. Were you ever interested in } \\
\text { participating in the official exams of } \\
\text { Spanish language before the law? After } \\
\text { the law? }\end{array}$ & $\begin{array}{l}\text { Pakistani nationals living in Spain were not } \\
\text { interested in participating in the official exams } \\
\text { of Spanish language. Some of them did not } \\
\text { even know they existed. }\end{array}$ & $\begin{array}{l}\text { All candidates stated that Pakistani nationals } \\
\text { living in Spain are flooding the branches and } \\
\text { Examination Centers of Instituto Cervantes in } \\
\text { order to participate in the exams. }\end{array}$ \\
\hline $\begin{array}{l}\text { 7. Before the law, were you ever } \\
\text { interested in learning about the culture } \\
\text { and constitution of Spain? After the } \\
\text { law? }\end{array}$ & $\begin{array}{l}\text { A large number of Pakistani nationals living in } \\
\text { Spain were not interested in learning about the } \\
\text { societal norms, culture and constitutional laws } \\
\text { of the country. }\end{array}$ & $\begin{array}{l}\text { All candidates stated that due to the new law, } \\
\text { Pakistanis are now forced to learn about the } \\
\text { societal norms of the country, the cultural } \\
\text { heritage and the rights and obligations of every } \\
\text { citizen of the country outlined in the Spanish } \\
\text { Constitution. They also stated that the new } \\
\text { knowledge has benefitted them. }\end{array}$ \\
\hline
\end{tabular}

\section{Results}

\subsection{Language Proficiency Levels of the Pakistani Candidates in Lahore}

Al-Andalus Institute of Languages has observed that the great majority of the candidates (95\%) do not have more than a high school education and they work in grocery stores, restaurants, kabab shops and other sorts of jobs that do not require a university degree. Several of the candidates only attended primary school.

Due to this fact, a high percentage of them seemed to present oral and listening skills that are more developed than their writing and reading skills. Due to ethical considerations the names of the candidates are omitted. However, an analysis has been made that shows the results of the candidates who travel from Barcelona to Lahore to participate in the exams in the last two years. Al-Andalus Institute of Languages has held various examinations with a number of students of each level participating in the exams. The sample of this study is 34 Pakistani candidates from Barcelona who participated in the DELE A2 examination and their collective result on each part of the exam. Candidates for the DELE A2 examination who resided in Pakistan have not been included in this study. Due to the addition of groups (both exams of Group 1 and both exams of Group 2) some students who passed the DELE A2 examination may have failed any of the parts. Their collective result is not reflected in the following table, only individual proficiencies results. Some of the candidate passed in spite of failing any of the parts due to the collective result. 
Table 3. Results of Pakistani candidates from Barcelona

\begin{tabular}{lllll}
\hline $\begin{array}{l}\text { TOTAL NUMBER OF } \\
\text { CANDIDATES }\end{array}$ & $\begin{array}{l}\text { Passed } \\
\text { Reading }\end{array}$ & $\begin{array}{l}\text { Passed } \\
\text { Writing }\end{array}$ & $\begin{array}{l}\text { Passed } \\
\text { Audio }\end{array}$ & $\begin{array}{l}\text { Passed } \\
\text { Oral }\end{array}$ \\
\hline FOR A2 DELE EXAMS & 18 & 17 & 20 & 25 \\
PERCENTAGES & $52.94 \%$ & $50 \%$ & $58.82 \%$ & $73.52 \%$ \\
\hline
\end{tabular}

This proves that those Pakistani students who come from Barcelona to take their examinations are in general more proficient in two of the exam skills, listening and speaking.

\section{Discussion}

The first table (2) concluded that although the average Pakistani place of residence within their ghettos has not changed and the way and languages they relate to each other within their community has not changed they have now been forced to learn Spanish language and increase their proficiency levels and language skills. Further, although their intrinsic level of motivation towards learning Spanish language has not increased there is an instrumental motivation that leads them towards the learning of the language as the main purpose is to attain nationality. This is proven by the fact that before the law, these individuals had not enrolled in Spanish language courses, neither in the official exams of Spanish language administered by Instituto Cervantes. Furthermore, the same is true for the knowledge of the culture and the Constitution of Spain. Before the law they had not shown any interest in learning about it, the law forced them to study it so that they could pass the CCSE exam, another stepping stone towards achieving their goal.

Table number three proved the information of table number two in regards to language proficiency and skills. In terms of reading proficiency slightly more than half was able to pass this part of the exam while in the second part of Group 1 (Reading and Writing), the writing part, only $50 \%$ was able to pass this activity. Since the candidates have usually not attended classes prior to the examination their errors are fossilized and it entails a great level of difficulty to correct the errors they make. Whether they have attended classes or not for the purpose of the examination, table number three shows a higher level of proficiency in terms of listening skills with $58.82 \%$ and speaking with $73.52 \%$. This also reflects their activities in their daily life. Since this group is usually an unskilled labor group, they are perhaps better trained in communication skills to a limited level required by their daily activities in their place of employment. During the exams, another factor came up which is that they do memorize certain topics for the preparation of the examination which may also influence the overall exam result.

\section{Conclusion}

The new law of 2015 has created a new environment for the Pakistani residents of Spain, who usually live in the ghettos of Barcelona without much communication with the Spanish population, or perhaps engaged in learning just a limited vocabulary enough to survive in their environment. The investigation revealed certain changes in their lifestyles as a result of the implementation of the recent law which coincides with those implemented by the immigration departments of other countries such as Germany, France, Canada, United States and others. A positive change has been observed by which those Pakistani candidates are now learning basic skills of the language as well as basic socio-cultural knowledge directed to be able to operate as a Spanish citizen in the new culture. The government of Spain's policy is positive in terms of creating steps for the integration of the immigrants. When tested these candidates to the A2 exams proved that they are better prepared for listening and speaking than for reading and writing. The reason for this is the level of education they have received, which is not higher than high school and in many cases only primary school. This level of education translates on their approach to learning and their cognitive abilities, as well as their socio-economic status and place of residence within the Pakistani ghetto of Barcelona, located around the Ramblas and El Raval areas.

\section{References}

Beltrán, A. J., \& Sáiz, L. A. (2007). La comunidad pakistaní en España. Anuario Asia-Pacífico 2007, 207-216.

Aubia, M. S., \& Roca, J. R. (2005). Pakistanis in Spain\&58; a study based on the community living in the city of Barcelona. Revista CIDOB d'Afers Internacionals, 97(68), 97-118.

Beltrán, A. J., \& Amelia, S. L. (2008). La comunidad Pakistaní en España. Anuario Asia-Pacifico. Real Instituto Elcano, Fundacion CIDOB, Casa Asia, Barcelona, pp. 407-416.

Council of Europe. (2001). Common European Framework of References for Languages: Learning, teaching and assessment. Cambridge: Cambridge University Press. 
De Jong, J. H., Lennig, M., Kerkhoff, A., \& Poelmans, P. (2009). Development of a test of spoken Dutch for prospective immigrants. Language Assessment Quarterly, 6(1), 41-60. http://dx.doi.org/10.1080/15434303.2015.1061530

Ellis, R., \& Gary, B. (2005). Analysing Learner Language. London: Oxford University Press.

Garha, N. S., Galeano, J., \& Valls, A. D. (2016). South Asian immigration to Spain: Socio-demographic profile and territorial distribution, 2000-2014. Asian and Pacific Migration Journal, 25(2), 191-205. https://doi.org/10.1177/0117196816639166

Instituto

Cervantes

Page.

(2015a). http://www.cervantes.es/sobreinstitutocervantes/prensa/2015/noticias/inauguracionquijotes-por-el-mundo.ht $\mathrm{m}$

Instituto Cervantes. (2015b). http://www.cervantes.es/sobre_instituto_cervantes/informacion.htm. Translation by the author.

Instituto Nacional de Estadística. (2016). Población Estadística del Padrón Continuo a 1 de enero de 2015. Datos a nivel nacional, comunidad autónoma y provincia. Retrieved from http://www.ine.es/jaxi/Datos.htm?path=/t20/e245/p04/a2007/10/\&file=00000010.px\&type=pcaxis and $\mathrm{http}: / /$ www.ine.es/jaxi/Datos.htm?path=/t20/e245/p04/a2015/10/\&file=00000010. px\&type=pcaxis

Jupp, J., \& Clyne, M. (2010). Multiculturalism and Integration. A Harmonious Relationship. Anu E Press. The Australian National University.

Little, D. (2005). The Common European Framework and the European Language Portfolio: Involving learners and their judgements in the assessment process. Language Testing, 22(3), 321-336. https://doi:10.1017/S0261444806003557

Lloyd, B. (2014). Should your student take 4 years of a foreign language? The College Money Guys. Retrieved from http://www.thecollegemoneyguys.com/should-you-or-your-student-take-4-years-of-foreign-language/

MacIntyre, P. D., Noels, K. A., \& Clément, R. (1997). Biases in self - ratings of second language proficiency: The role of language anxiety. Language learning, 47(2), 265-287. https://doi:10.1111/0023-8333.00025

Molina, J. L., Valenzuela, H., García-Macías, A., Pampalona, J., \& Lubbers, M. (2013). Measuring Social Capital in Ethnic Enclaves: Indians in Lloret de Mar, and Pakistani in Barcelona city. In the Handbook of Research Methods and Applications on Social Capital. Edward Elgar Publisers. (Pre-print Edition).

Moreras Palenzuela, J. (2005). ¿Ravalistán? Islam y configuración comunitaria entre los paquistaníes en Barcelona. Revista CIDOB d'Afers Internacionals, (68), 119-132.

Rattansi, A. (2011). Multiculturalism. A Very Short Introduction. London: Oxford University Press. https://doi.org/10.1093/actrade/9780199546039.001.0001

Carvajal, E. (2003) La vivienda de los inmigrantes en Barcelona: el caso del colectivo Pakistani. Scripta Nova, VII(146), 59. Retrieved from http://www.ub.edu/geocrit/sn/sn-146(059).htm

Shohamy, E. (2009). Language tests for immigrants: Why language? Why tests? Why citizenship. Discourses on language and integration, pp. 45-59. https://doi.org/10.1075/dapsac.33.07sho

Staff, R. (2008). "Britain's Pakistani community" The Daily Telegraph. Retrieved from http://www.telegraph.co.uk/news/uknews/3533486/Britains-Pakistani-community.html

Staff, R. (2011). Barcelona concentra más de la mitad de los pakistaníes de España. La Vanguardia. Retrieved from http://www.lavanguardia.com/local/barcelona/20110311/54124995534/barcelona-concentra-mas-de-la-mita d-de-los-pakistanies-de-espana.html

\section{Notes}

Note 1. Ministerio de Justicia

http://www.mjusticia.gob.es/cs/Satellite/Portal/es/ciudadanos/tramites-gestiones-personales/nacionalidad-residen cia

Note 2. Interview conducted on $19^{\text {th }}$ October, 2016.

Note 3. DELE Exams price list of Instituto Cervantes. 
Note 4. For example, the Prisma collection by Edinumen Publishing Company with Prisma Comienza (A1) and Prisma Continua (A2) and others.

Note 5. Her qualifications are Masters Degree in Teaching Spanish as a Second Language, Master of Science and Hispanic Linguistics and $\mathrm{PhD}$ in Spanish Language and General Linguistics.

Note 6. Goethe Institute and French Alliance.

\section{Copyrights}

Copyright for this article is retained by the author(s), with first publication rights granted to the journal.

This is an open-access article distributed under the terms and conditions of the Creative Commons Attribution license (http://creativecommons.org/licenses/by/4.0/). 